\title{
Multimedia Addiction and its impact on adolescent's personality
}

\author{
Vandana Goswami ${ }^{1}$, Divya Rani Singh ${ }^{2}$ \\ ${ }^{1}$ Research Scholar, Department of Home Science, D.D.U. Gorakhpur University, Gorakhpur, U.P. \\ ${ }^{2}$ Associate Professor, Department of Home Science, DDU Gorakhpur University, Gorakhpur, U.P. \\ E-mail - vandanagoswami55@gmail.com \\ Corresponding Author - Vandana Goswami
}

\begin{abstract}
Background: Multimedia addiction is a common and emerging problem seen in adolescents in all major cities in India. The present study sought to investigate multimedia addiction and its impact on adolescent's personality.

Methodology: This study involved 200 adolescent students (100 male and 100 female) studying in randomly selected higher secondary schools in Gorakhpur city. Four questionnaire were administered viz. Young's Internet Addiction Test (YIAT 20), Bianchi and Philips Mobile Problem Use Scale, Lemmens Game Addiction Scale applied for measured to Multimedia addiction in respondents, whereas Costa and McCrae The Revised NEO Personality Inventory (NEO PI-R) was use for concise measure of the five major dimensions.

Results: The result showed that $57 \%$ adolescents addicted to Multimedia and there was significant difference between addicted and non addicted personality dimensions among adolescents.

Conclusions: Multimedia addiction as problem warrants further study in adolescents and larger multicentre studies in this regard are needed.
\end{abstract}

Key words: narcissism, forgiveness, college students.

(Paper received $-13^{\text {th }}$ September 2017, Peer review completed $-1^{\text {st }}$ October 2017)

(Accepted $-4^{\text {th }}$ October 2017)

\section{INTRODUCTION}

Present time adolescents are continuously using multimedia in their daily life and studies, but they are not mature to understand bad effects associated with addictive use of these multimedia. The dependency of adolescents on multimedia has reached at such level that, without these adolescents can't think a step forward in the direction of their growth and development [1]. The effect of multimedia addiction in the lives of adolescents cannot be ignored because almost every adolescents use the Mobile, Internet, Video game etc on daily basis. According to Young [2] addiction to technology is a habitual compulsion to engage in using technology instead of using it to address life's problems. Adolescents use technology as a coping mechanism to avoid conflict.

Excessive use of Multimedia makes the adolescents strong in technical skills but make them weak in real life practical skills. It takes the adolescents away from the reality world and helping them to live in their imaginary world. Due to the time spent on the multimedia through Internet, mobile, video game etc, the adolescents are refrained outdoor activities with their friends and families. When adolescents play video games and they can't achieve their set target, their anxiety and depression level increases very high. Violent content of video games create violent in their mind and affect their personality negatively [3]. 
The adolescent is psychologically addicted to the social Medias like face book, Instagram, Whatsapp, Twitter, etc. and they are spending so much time on social networking sites. The social networking sites are totally changed adolescent's vocabulary and increase poor grammar and spelling, sending message through social networking sites has no grammar. The multimedia has demonstrated potentially profound effects both positive and negative, on adolescent's social, cognitive and personality development. Adolescent's personality development is largely affected by all form of multimedia. Early warning sign of Multimedia addictions are related to negative changes in adolescent's personality [4].

One of the most recent models for studying personality is the five-factor model (FFM). In recent years, the five-factor model has become the dominant model in dispositional trait psychology [5]. Many factoranalytic theorists believe that there are five to eight elements that determine our personality [6]. Big Five traits (openness to experience, conscientiousness, extraversion, agreeableness and neuroticism) is a well-established and unifying framework to measure and understand personality traits [7].

\section{Neuroticism}

Neuroticism is characterized by individual's susceptibility to worry, anxiety, anger and general emotional instability [8]. Conversely known as Emotional Stability, it reflects the tendency to experience negative emotions [9] and measures the individual's emotional stability and personal adjustment to circumstances [10].

\section{Extraversion}

According to Bakker and others [11], Extraversion is characterized by a tendency to be self-confident, dominant, active and excitement seeking. Extraverts show positive emotions, higher frequency and intensity of personal interactions and a higher need of stimulation. Extrovert individuals are friendly, sociable, chatty, fluent with active behavior, whereas introverts are individuals who are not social and have friendless behavior.

\section{Openness}

Openness to experience is much less well known than $\mathrm{N}$ or $\mathrm{E}$. This factor refers to the individual's tendency to experience new ideas including new products and services [12]. It distinguishes inventive, imaginative and creative people from modest conservative people [9].

\section{Agreeableness}

According to McElroy [13] people who are agreeable are sympathetic, good natured, cooperative and forgiving. They help others and expect help in return.

\section{Conscientiousness}

Conscientious people are responsible, organized and persevering. They achieve high levels of success through focused planning and persistence [6].

The objectives of the study are -

1. To study the extent of Multimedia addiction among adolescent.

2. To find out differences between multimedia addicted and non-addicted adolescents personality.

\section{METHODOLOGY}

\section{Sample}

The sample consists of 200 adolescents (100 male and 100 female) studying in higher secondary schools in Gorakhpur city were selected from using purposive random sampling.

\section{Tools used in the study}

1. Young's Internet Addiction Test (YIAT 20) - was applied to qualify for the extent of Internet addiction. The Internet Addiction Test is the first valid and reliable measurement of internet addiction. It measures Internet addiction in mild, moderate and severe levels. Each answer is scored on a Likert scale from 1 to 5 . In a way that, score $1=$ rarely, $2=$ occasionally, $3=$ frequently, $4=$ often, and $5=$ always. The final score is obtained by summing the scores of all questions. The higher score represents a greater level of addiction. The total score 20-49 represents a mild 
addiction, 50-79 represents moderate addiction, and 80-100 represents severe addiction. The instrument has exhibited good psychometric properties in previous researches. The reliability for this questionnaire is 0.899 in Cronbach's Alpha [14].

2. Bianchi and Philips Mobile addiction test - was applied for measured to Mobile addiction in respondents. Mobile Phone Problem Use Scale is a 27- item self-report scale. Mobile Phone Problem Use Scale listed a series of questions based on the Addiction literature and in particular, what is currently known about behavioral and technological addiction. Twenty seven questions covered the issues of tolerance, escape from others problems, withdrawal, craving and negative life consequences in the areas of social, familial, work and financial difficulties. A five-point Likert scale was utilized to score the MPPUS with responses ranging from not true at all (1), Somewhat true (2), True (3), Very True (4) and Extremely True (5). Scores on the MPPUS range from 27 to 135 , with higher scores 50 and above indicating greater levels of dependence. If the respondents score 50 and above, then they are taken as addictive to mobile addiction, whereas respondents scoring below 50 are taken as not addictive. The authors of this scale analysis of the internal consistency of the MPPUS yielded a Cronbach's alpha of 0.93 , from which it can be implied that the measure is reliable and has high internal consistency between items [15].

3. Lemmen's Game Addiction Scale - was used for measured to Game Addicted respondents. The Game Addiction Scale was 21 questions and contains seven items that measure symptoms of video game addiction over the past six months. These are: How often during the last six months: 1. Did you think about playing a game all day long? (Salience), 2. Did you spend increasing amounts of time on games? (Tolerance), 3. Did you play games to forget about real life? (Mood modification), 4. Have others unsuccessfully tried to reduce your game use? (Relapse), 5. Have you felt bad when you were unable to play? (Withdrawal), 6. Did you have fights with others (e.g., family, friends) over your times spent on games? (Conflict), 7. Have you neglected other important activities (e.g., school, work, sports) to play games? (Problems). The items on the Game Addiction Scale are rated on a 5-point Likert scale: 1 (never), 2 (rarely), 3 (sometimes), 4 (often) and 5 (very often). As suggested by the authors of the scale, an item was considered endorsed when a respondent scored 3 or higher. The cut-off for addiction was in the present study set to a minimum score of three on at least four of the seven items. The reliability for this scale is 0.84 in Cronbach's Alpha [16].

4. Personality Assessment Test - The Revised NEO Personality Inventory (NEO PI-R) for concise measure of the five major dimensions, or domains of personality and some of the more important traits or facets that define each domain. This questionnaire was developed by Costa and McCrae and this personality test was consists of 240 items answered on a 5-point scale. It was self administered and appropriate for male and female respondents. For the Revised NEO Personality Inventory, the test manual provides good support for both reliability and validity. Internal consistency coefficients were calculated at 0.86 to 0.95 for both the forms (self and observer) [17].

\section{STATISTICAL ANALYSIS}

Statistical Package for the Social Sciences (SPSS) IMB SPSS version 20 was used for the statistical analysis, and the obtained data were analyzed based on the objectives by using descriptive and inferential statistics. Frequency and percentage were used to assess the extent of Multimedia addiction and ANOVA were used to assess the difference between personality of addicted and non-addicted adolescents.

\section{RESULTS}

Table 1 - Frequency of Multimedia addiction

\begin{tabular}{|c|c|c|}
\hline Addiction & Frequency & Percentage \\
\hline Addicted & 114 & 57 \\
\hline Not addicted & 86 & 43 \\
\hline
\end{tabular}


The above table shows that $57 \%$ of adolescents addicted to Multimedia, whereas $43 \%$ were not addicted.

Table 2 - Summary Table of Neuroticism (N) Personality Dimension as a Function of Addiction and Gender

\begin{tabular}{|c|c|c|c|}
\hline Source of Variation & Df & MS & F \\
\hline Addiction & 1 & 5297.59 & $66.36^{* *}$ \\
\hline Gender & 1 & 1.586 & .020 \\
\hline Addiction ${ }^{*} G e n d e r$ & 1 & 350.55 & $4.39^{*}$ \\
\hline Error & 196 & 79.82 & \\
\hline Total & 200 & & \\
\hline \multicolumn{2}{|c|}{ (Note: $\left.{ }^{*} \mathrm{p}<0.05,{ }^{* *} \mathrm{p}<0.01\right)$}
\end{tabular}

Table 3 - Mean and SD of Neuroticism (N) Personality Dimension as a Function of Addiction and Gender

\begin{tabular}{|c|c|c|c|}
\hline Addiction & Gender & M & SD \\
\hline Addicted & Male & 96.06 & 9.95 \\
\hline & Female & 98.59 & 10.90 \\
\hline & Total & 97.14 & 10.40 \\
\hline Not addicted & Male & 88.22 & 8.19 \\
\hline & Female & 85.33 & 5.12 \\
\hline & Total & 86.51 & 6.66 \\
\hline
\end{tabular}

Table 2 presents the summary of Neuroticism $(\mathrm{N})$ Personality dimension as a function of addiction and gender. The effect of addiction was found to be significant for Neuroticism Personality dimension $[\mathrm{F}=$ $(1,196) 66.36 \mathrm{p}<0.01]$ but the effect of gender was not found to be significant for Neuroticism Personality dimension $[F=(1,196) 0.020 \mathrm{p}>0.05]$. The interaction effect between addiction and gender was also found to be significant $[\mathrm{F}=(1,196) 4.39 \mathrm{p}<0.05]$.

The respective mean suggested that addicted male and female have higher score on the Neuroticism Personality dimension compared to non addicted male and female. The result indicated that Multimedia addicted adolescents have Higher score on this Personality dimension $(M=97.14)$ compared to non addicted adolescents $(\mathrm{M}=86.51)$ (Table 3$)$.

Table 4- Summary Table of Extraversion (E) Personality Dimension as a Function of Addiction and Gender

\begin{tabular}{|l|l|l|l|}
\hline \multicolumn{1}{|c|}{ Source of Variation } & \multicolumn{1}{|c|}{ df } & \multicolumn{1}{c|}{ MS } & \multicolumn{1}{c|}{ F } \\
\hline Addiction & 1 & 11164.24 & $105.55^{* *}$ \\
\hline Gender & 1 & 9.910 & 0.09 \\
\hline Addiction ${ }^{*}$ Gender & 1 & 44.68 & 0.42 \\
\hline Error & 196 & 105.76 & \\
\hline Total & 200 & & \\
\hline
\end{tabular}

Table 4 presents the summary of Extraversion (E) Personality dimension as a function of addiction and gender. The effect of addiction was found to be significant for Extraversion Personality dimension $[F=(1,196) 105.55, p<0.01]$ but the effect of gender $[F=(1,196) .094, p>.05]$ and interaction effect was not found to be significant $[F=(1,196) .422, p>0.05]$ for Extraversion Personality dimension. 
Table 5- Mean and SD of Extraversion (E) Personality Dimension as a Function of Addiction and Gender

\begin{tabular}{|c|c|c|c|}
\hline Addiction & Gender & $\boldsymbol{M}$ & $\boldsymbol{S D}$ \\
\hline Addicted & Male & 111.43 & 13.19 \\
\hline & Female & 110.91 & 11.37 \\
\hline & Total & 111.21 & 12.39 \\
\hline Not addicted & Male & 125.77 & 8.57 \\
\hline & Female & 127.19 & 4.16 \\
\hline & Total & 126.61 & 6.33 \\
\hline
\end{tabular}

The respective mean suggested that addicted male and female have lower score on the Extraversion Personality dimension compared to non addicted male and female. It was found that Multimedia addicted adolescents have Lower score on this Personality dimension $(\mathrm{M}=11.21)$ compared to non addicted adolescents ( $\mathrm{M}=126.21)$ (Table 5).

Table 6- Summary Table of Openness (O) Personality Dimension as a Function of Addiction and Gender

\begin{tabular}{|c|c|c|c|}
\hline Source of Variation & df & MS & F \\
\hline Addiction & 1 & 4671.42 & $47.60^{* *}$ \\
\hline Gender & 1 & 77.85 & 0.79 \\
\hline Addiction* Gender & 1 & 200.37 & 2.04 \\
\hline Error & 196 & 98.12 & \\
\hline Total & 200 & & \\
\hline
\end{tabular}

(Note: ${ }^{*} \mathrm{p}<0.05,{ }^{* *} \mathrm{p}<0.01$ )

Table 7- Mean and SD of Openness (O) Personality Dimension as a Function of Addiction and Gender

\begin{tabular}{|c|c|c|c|}
\hline Addiction & Gender & M & SD \\
\hline Addicted & Male & 102.44 & 12.00 \\
\hline & Female & 105.77 & 10.81 \\
\hline & Total & 103.87 & 11.57 \\
\hline Not addicted & Male & 114.40 & 8.56 \\
\hline & Female & 113.62 & 6.17 \\
\hline & Total & 113.94 & 7.20 \\
\hline
\end{tabular}

Table 6 presents the summary of Openness (O) Personality dimension as a function of addiction and gender. The effect of addiction was found to be significant for Openness Personality dimension $[F=(1,196)$ $47.60, p<0.01]$ but the effect of gender $[F=(1,196) .793, p>0.05]$ and interaction effect between addiction and gender was not found to be significant $[F=(1,196) 2.04, p>0.05]$ for Openness Personality dimension. The respective mean suggested that addicted male and female have Lower score on the Openness Personality dimension compared to non addicted male and female. It was found that Multimedia addicted adolescents have Lower score on this Personality dimension $(\mathrm{M}=103.87)$ compared to non addicted adolescents $(\mathrm{M}=113.94)$ (Table 7).

Table 8 presents the summary of Agreeableness (A) Personality dimension as a function of addiction and gender. The effect of addiction $[F=(1,196) 22.63, p<0.01]$ and Gender $[F=(1,196) 4.84, p<0.05]$ was found to be significant for Agreeableness Personality dimension. The interaction effect between addiction and gender was also found to be significant $[\mathrm{F}=(1,196) 12.49, \mathrm{p}<0.01]$.

The respective mean suggested that addicted male and female have Lower score on the Agreeableness Personality dimension compared to non addicted male and female. It was found that Multimedia addicted adolescents have Lower score on this Personality dimension $(\mathrm{M}=102.80)$ compared to non addicted adolescents $(\mathrm{M}=109.93)$ (Table 9). 
Table 8- Summary Table of Agreeableness (A) Personality Dimension as a Function of Addiction and Gender

\begin{tabular}{|c|c|c|c|}
\hline Source of Variation & $\boldsymbol{d f}$ & $\boldsymbol{M S}$ & $\boldsymbol{F}$ \\
\hline Addiction & 1 & 2934.83 & $22.63^{* *}$ \\
\hline Gender & 1 & 628.50 & $4.84^{*}$ \\
\hline Addiction* Gender & 1 & 1620.20 & $12.49^{* *}$ \\
\hline Error & 196 & 129.68 & \\
\hline Total & 200 & & \\
\hline \multicolumn{2}{|c|}{ (Note: $\left.{ }^{*} \mathrm{p}<0.05,{ }^{* *} \mathrm{p}<0.01\right)$}
\end{tabular}

Table 9- Mean and SD of Agreeableness (A) Personality Dimension as a Function of Addiction and Gender

\begin{tabular}{|c|c|c|c|}
\hline Addicted & Gender & $\boldsymbol{M}$ & $\boldsymbol{S D}$ \\
\hline Addicted & Male & 101.86 & 11.09 \\
\hline & Female & 104.06 & 16.30 \\
\hline & Total & 102.80 & 13.56 \\
\hline Not addicted & Male & 115.54 & 9.51 \\
\hline & Female & 106.07 & 5.82 \\
\hline & Total & 109.93 & 8.83 \\
\hline
\end{tabular}

Table 10- Summary Table of Conscientiousness (C) Personality Dimension as a Function of Addiction and Gender

\begin{tabular}{|c|c|c|c|}
\hline Source of Variation & $d \boldsymbol{f}$ & $\boldsymbol{M S}$ & $\boldsymbol{F}$ \\
\hline Addiction & 1 & 11154.48 & $76.73^{* *}$ \\
\hline Gender & 1 & 908.76 & $6.25^{* *}$ \\
\hline Addiction* Gender & 1 & .035 & 0.00 \\
\hline Error & 196 & 145.36 & \\
\hline Total & 200 & \\
\hline \multicolumn{3}{|c|}{ (Note: $\left.{ }^{*} \mathrm{p}<0.05,{ }^{* *} \mathrm{p}<0.01\right)$} \\
\end{tabular}

Table 11- Mean and SD of Conscientiousness (C) Personality Dimension as a Function of Addiction and Gender

\begin{tabular}{|c|c|c|c|}
\hline Addiction & Gender & M & SD \\
\hline Addicted & Male & 110.58 & 13.40 \\
\hline & Female & 114.97 & 15.91 \\
\hline & Total & 112.47 & 14.63 \\
\hline Not addicted & Male & 125.91 & 9.22 \\
\hline & Female & 130.25 & 6.21 \\
\hline & Total & 128.48 & 7.83 \\
\hline
\end{tabular}

Table 10 presented the summary of Conscientiousness (C) Personality dimension as a function of addiction and gender. The effect of addiction $[F=(1,196) 76.73, p<0.01]$ and Gender $[F=(1,196) 6.25, p$ $<0.01$ ] was found to be significant for Conscientiousness Personality dimension. The interaction effect between addiction and gender was not found to be significant $[F=(1,196) 0.00, p>0.05]$. The respective mean suggested that addicted male and female have Lower score on the Conscientiousness Personality dimension compared to non addicted male and female. It was found that Multimedia addicted adolescents have Lower score on this Personality dimension $(\mathrm{M}=112.47)$ compared to non addicted adolescents $(\mathrm{M}=128.48)$ (Table 11). 


\section{DISCUSSION}

According to the obtained results in this study, the multimedia addiction in the adolescents was found to be very high and our result indicated that Multimedia addicted adolescents have higher score on Neuroticism Personality dimension compared to non addicted adolescents. The neurotic or emotionally unstable person may use multimedia like Internet, Mobile and Video game as a means of coping with stress and anxiety. A number of research studies have found that stress/ anxiety are related to problematic mobile phone use [18-20]. Other research has indicated that online gaming addiction may be related to neuroticism, anxiety, and sensation seeking [21].

Moreover, multimedia addicted adolescents have low score on Extraversion personality dimension compared to non addicted adolescents. This result was in the similar direction as that of the finding reported that adolescent Internet addicts score significantly lower on extraversion compared to nonaddicted adolescents [22]. Persons with lower extroversion (introverts) are less likely to communicate with others face to face due to their shyness and feelings of shame [23].

Our finding revealed that multimedia addicted adolescents have Lower score on the Openness Personality dimension compared to non addicted adolescents. This finding is somewhat surprising in that previous studies has shown that a positive relationship between openness and social media usage [24-26]. Similarly, Teng [27] found that gamers had significantly higher score on openness compared to non gamers.

Results showed that multimedia addicted adolescents have Lower score on the Agreeableness Personality dimension compared to non addicted adolescents. This finding of the present study is in the line with researchers [28] who reported that more disagreeable individuals spend more time on calls and that disagreeable individuals with lower self-esteem spent more time using instant messaging and reported stronger instant messaging addictive tendencies. Research found that agreeability was associated with the use of cell phones to play games [29].

Data revealed that multimedia addicted adolescents have Lower score on the Conscientiousness Personality dimension compared to non addicted adolescents. This finding is a replication of previous researches. Problematic online game use has been associated with lower conscientiousness [30-31]. Similarly, researchers [32] found that Facebook users tend to be less conscientious and socially lonely than non-users. Muller and others [33] found that people with a high level of neuroticism as well as low level of extraversion and conscientiousness are likely to be internet addicted.

In summary, adolescents who scored higher on multimedia addiction and spent more time using the multimedia, they had a low level of the big five factors extraversion, openness, agreeableness, neuroticism and conscientiousness. Adolescents who scored higher on multimedia scales were rather introvert and neurotic and had a low level of agreeableness, conscientiousness and openness, seem convincing adolescents for increasing the addictive use of multimedia as these associations are found in multiple studies. Looking at the above findings it was realized that continues use of multimedia gadgets without any restriction, become very serious and they affects negatively on adolescents personality.

\section{REFERENCES}

1. Redding CA, Prochaska JO, Pallonen UE, Rossi JS, Velicer WF, Rossi SR, Greene GW, Meier KS, Evers KE, Plummer BA, Maddock JE. Transtheoretical individualized multimedia expert systems targeting adolescents' health behaviors. Cogn Behav Pract 1999;6(2):144-53.

2. Young KS. Internet addiction: The emergence of a new clinical disorder. Cyberpsychol Behav 1998;1(3):23744.

3. Kirsh SJ. The effects of violent video games on adolescents: The overlooked influence of development. Aggress Viol Behav 2003;8(4):377-89.

4. O'Keeffe GS, Clarke-Pearson K. The impact of social media on children, adolescents, and families. Pediatrics 2011;127(4):800-4.

5. Digman JM. Personality structure: Emergence of the five-factor model. Ann Rev Psychol 1990;41(1):417-40.

6. McCrae RR, Costa PT. Validation of the five-factor model of personality across instruments and observers. J Personal Soc Psychol 1987;52(1):81-90.

7. Costa Jr PT, Widiger TA. Personality disorders and the five-factor model of personality. American Psychological Association; 1994. 
8. Markey PM, Markey CN. Vulnerability to violent video games: a review and integration of personality research. Rev Gen Psychol 2010;14(2):82-91.

9. Buss DM. Social adaptation and five major factors of personality. The five-factor model of personality: Theoret Perspect 1996:180-207.

10. Maltby J, Day L, Macaskill A. Personality Individual Differences and Intelligence. Pearson Education Ltd., Essex, UK.

11. Baker A, Van Der Zee K, Lewig K. The relationship between the big five personality factors and burnout: A study among volunteer counselors. J Soc Psychol 2006;146(1):31-50.

12. Wood AM, Linley PA, Maltby J, Baliousis M, Joseph S. The authentic personality: A theoretical and empirical conceptualization and the development of the Authenticity Scale. J Couns Psychol 20081;55(3):385-93.

13. McElroy JC, Hendrickson AR, Townsend AM, De Marie SM. Dispositional factors in internet use: personality versus cognitive style. MIS Quarterly 2007;31(4):809-20.

14. Young KS, Rogers RC. The relationship between depression and Internet addiction. Cyberpsychol Behav 1998;1(1):25-8.

15. Bianchi A, Phillips JG. Psychological predictors of problem mobile phone use. Cyberpsychol Behav 2005;8(1):39-51.

16. Lemmens JS, Valkenburg PM, Peter J. Development and validation of a game addiction scale for adolescents. Media Psychol 2009;12(1):77-95.

17. Costa PT, Mccrae RR. Revised NEO personality inventory (NEO Pi-R) and NEO five factor inventory (NEO FFI) professional manual. Odessa, Florida: Psychological Assessment Resource ; 1992.

18. Beranuy M, Oerst U, Carbonell X, Chamarro A. Problematic Internet and mobile phone use and clinical symptoms in college students: the role of emotional intelligence. Comp Hum Behav 2009;25:1182-7.

19. Ha JH, Chin B, Park DH, Ryu SH, Yu J. Characteristics of excessive cellular phone use in Korean adolescents. Cyberpsychol Behav 2008;11:783-4.

20. Reid DJ, Reid FJM. Text or talk? Social anxiety, loneliness and divergent preference for cell phone use. Cyberpsychol Behav 2007;10:424-35.

21. Mehroof M, Griffiths MD. Online gaming addiction: The role of sensation seeking, self- control, neuroticism, aggression, state anxiety, and trait anxiety. Cyberpsychol Behav 2010;13(3):313-6.

22. Huang X, Zhang H, Li M, Wang J, Zhang Y, Tao R. Mental Health, Personality and Parental Rearing Styles of Adolescents with Internet Addiction Disorder. Cyberpsychol Behav Soc Network 2010;13(4):401-6.

23. Lavin MJ, Yuen CN, Weinman M, Kozak K. Internet dependence in the collegiate population: the role of shyness. Cyberpsychol Behav 2004;7(4):379-83.

24. Correa T, Hinsley AW, de Zuniga HG. Who interacts on the Web? The intersection of users' personality and social media use. Comp Hum Behav 2010;4(5):247-53.

25. Wang JL, Jackson LA, Zhang DJ, Su ZQ. The relationships among the Big Five Personality factors, selfesteem, narcissism, and sensation-seeking to Chinese University students' uses of social networking sites (SNSs). Comp Hum Behav 2012;28(6):2313-9.

26. Quintelier E, Theocharis Y. Online political engagement, Facebook, and personality traits. Soc Sci Computer Rev 2013;31(3):280-90.

27. Teng C. Personality differences between online game players and non-players in a student sample. Cyberpsychol Behav 2008;11(2):232-4.

28. Ehrenberg AS, Juckes KM, White H, Walsh SP. Personality and self-esteem as predictors of young people's technology use. Cyberpsychol Behav 2008;11(6):739-41.

29. Phillips JG, Butt S, Blaszczynski A. Personality and self-reported use of mobile phones for games. Cyberpsychol Behav 2006;9(6):753-8.

30. Huh S, Bowman ND. Perception of and addiction to online games as a function of personality traits. J Media Psychol 2008;13:1-31.

31. Peters CS, Malesky LA. Problematic usage among highly-engaged players of massively multiplayer online role playing games. Cyberpsychol Behav 2008;11:481-4.

32. Ryan T, Xenos S. Who uses Facebook? An investigation into the relationship between the Big Five, shyness, narcissism, loneliness, and Facebook usage. Comp Hum Behav 2011;27(5):1658-64.

33. Muller KW, Koch A, Dickenhorst U, Beutel ME, Duven E, Wolfling K. Addressing the question of disorder- specific risk factors of internet addiction: a comparision of personality traits in patients with addictive behaviors and co-morbid Internet addiction. Bio Med Research International. http://dxdoi.org/10.1155/20/3/54634

Acknowledgements - Nil ; Source of Funding - Nil ; Conflict of Interest - Nil 